This is an author produced version of a paper published in Landscape Research.

This paper has been peer-reviewed and is proof-corrected, but does not include the journal pagination.

Citation for the published paper:

Butler, Andrew \& Berglund, Ulla. (2014) Landscape Character Assessment as an Approach to Understanding Public Interests within the European Landscape Convention. Landscape Research. Volume: 3, Number: 39, pp 219-236.

http://dx.doi.org/10.1080/01426397.2012.716404.

Access to the published version may require journal subscription.

Published with permission from: Taylor \& Francis.

Standard set statement from the publisher:

"This is an Accepted Manuscript of an article published in LANDSCAPE RESEARCH in 2014, available online: http://www.tandfonline.com/10.1080/01426397.2012.716404 ."

Epsilon Open Archive http://epsilon.slu.se 


\section{Landscape Character Assessment as an approach to understand public interests within the European Landscape Convention}

Andrew Butler \& Ulla Berglund

Swedish University of Agricultural Science, Stad och Land, Ulls Väg 28, Uppsala, SE 750 07, Sweden,

Abstract The European Landscape Convention’s (ELC) definition of landscape, “an area, as perceived by people...” places the public central to any understanding of landscape. This paper argues for 'just' involvement of the public and looks at how the focus of landscape as a perceived entity has been taken up within Landscape Character Assessment (LCA), an approach applied in the England and Scotland for implementing the ELC. Based on a conceptual framework grounded in perception as a phenomenological experience of landscape and informed by principles of participation, LCA's from 2007 to 2011 have been assessed as to how public involvement has been considered. The results show that only a quarter of all assessments accessed involved the public, and that among these there is great disparity in the degree to which the public is engaged.

\section{Introduction}

Landscape has been referred to as an integrating, holistic concept, which provides common ground for diverse disciplines and actors to address shared problems (Tress et al., 2003; Naveh, 2001; Fry, 2001). Yet the concept landscape is situated in an increasingly complex social and economic context. Building on Castells’ thesis of the 'Information age' it has been noted that shared values diminish, and that conflict and tension heightens as the diversity of values increases (Healey, 1996; Innes, 2003; Tress et 
al., 2003). Competing values are seen as being founded on technical advances, increased mobility and contact between diverse cultures. Landscape can be considered one of the arenas where these contested values can create conflict, as a diversity of users and the interests they bring with them vie for limited resources.

The significance of landscape for the well-being of individuals and society is well recognised (Luginbühl, 2006; EEA, 2007) as is the implication of quality of place for attracting local businesses and population into competing urban regions (Selman, 2006). At odds with this realisation of the benefits of landscape as a resource is the frequently commented perception of deterioration of the landscape across Europe (Buchecker et al, 2003).

It is within this context that the European Landscape Convention (ELC) was conceived. As the first regional international treaty concerning landscape (Prieur, 2006), the ELC sits under the auspices of the Council of Europe (CoE). As such the convention can be seen as a tool to forward the CoE's objectives for democracy, extension of human rights, and raising awareness of European cultural identity and diversity (CoE, 2011). Unlike the European Union or European Commission, the work of the CoE does not constitute law nor represent the power of the state but can be viewed as more of a "moral authority” (Olwig, 2007). This position allows individual signatory states to choose the means to fulfil the obligations of the convention from within their own legal system and national planning traditions (Prieur, 2006). In such a way the aim of the Convention is not to develop a new order within landscape dictated from Europe, but to provide individual states a base on which to develop their own principles, strategies, guidelines and tools for their own landscapes (CoE, 2008). 
Central to the Landscape Convention is the definition of landscape: "an area, as perceived by people, whose character is the result of the action and interaction of natural and/or human factors” (CoE, 2000a). Being recognised as an entity "perceived by people” moves the focus of landscape from being a purely physical area to being dependent on individuals and society to provide it with meaning. Such a definition promotes landscape as the domain of society, providing a space for democratising landscape as recognised as a common resource. If landscape is to be understood in such light then there is a need to access what values society places on the landscape

It is the centrality of the public to landscape which will be taken up in this paper. The paper will gauge how landscape character assessment (LCA), a recognised tool for implementing the ELC in England and Scotland, addresses issues of inclusion of the public within its approach (Natural England, 2009). The aim of the research has been to gain an understanding of if and how public knowledge of landscape has fed into landscape assessments. This is considered through the lenses of a phenomenologically guided view of landscape, and principles of open and just participation

The paper will begin by developing a theoretical framework for addressing public involvement in landscape issues. This starts by looking at the concept of landscape perception and the impact this has on public involvement. There after we consider some of the theoretical and practical issues relevant for participation before considering what public inclusion within the ELC entails. The LCA approach is then introduced: what the principles are behind the approach and how inclusion of the public is recognised within its guidelines. The paper reviews LCAs undertaken from 2007-2011 to assess how public inclusion is put into practice, and finally draws conclusions from these results. 


\section{Landscape Perception}

The ELC views landscape as an expression of the perception of an area shared by people as opposed to being predefined by nature. Such a definition of landscape means that an understanding of the Convention hinges to an extent on the interpretation given to ‘perception’ (Groening, 2007). In a natural science context perception can be seen as a physiological response to the environment, a purely sense related perception. In social science the concept of perception is related to an intellectual/cognitive sense of perceiving. Within social science studies, research into perception of environment has been primarily the domain of environmental psychology. This work has been wide ranging, from value systems to visual preferences. The latter, visual preferences, sees human connection with the landscape as a predominantly passive relationship (Wylie, 2007) and diminishing the focus of other human environment relationships (Clemetsen et al, 2011). It is such an approach which has had most prevalence in landscape planning, for example through landscape characterisation.

A more holistic approach to perception of landscape can be derived from phenomenology, where landscape perception is seen as involving direct physical contact and experience with the simultaneous use of all senses. The archaeologist Christopher Tilley in his writing on landscape phenomenology defines perceptions and experiences of landscape as being intertwined with the world in which we live (Tilley, 2004). This is in a similar vein to Tim Ingold's concept of landscape as “...the world as it is known to those who dwell therein, who inhabit its places and journey along the paths connecting them” (Ingold, 2000 p.194). In other words landscape becomes a 'lifeworld', an arena for 
engagement and involvement where the body meets its surroundings. This moves landscape from being a viewed image to a collection of practices, where perceptions are created by the act of 'landscaping' or being engaged in the landscape. Where perception of landscape relies on more than just the physical components, it also rests on the activities that occur in that landscape and the individual's thoughts, meanings and understandings (Canter, 1977). From a phenomenological standpoint landscape can be seen as a record of all who have dwelt in that landscape and left traces of self within it (Ingold, 2000).

Through the interaction between body and landscape and the body’s spatial framework the landscape is perceived. It can be said that an understanding of landscape relates to the characteristics of the individual and how the individual engages with their surroundings. The result of this is that different people experience different landscapes at the same location and time (Uzzell, 1991). Individuals' experience with landscape can be seen to be private encounters only made accessible to others through conveyance as a concept expressed and made legible through shared language.

These bodily encounters are tied to socialised cultural contexts (Clemetsen et al, 2011) and impacted on by a multitude of other acts of landscaping. In such a way it can be seen that perception is relational rather than primarily subjective, filtered through “social structures and fostered through socialization” (Hague \& Jenkins, 2005). This allows a collective understanding to form. In such a way landscape provides an anchor of shared understanding between people, creating a past and a future that binds them together, developing collective identity (Oreszczyn \& Lane, 2000). However development of these commonalities results in a loss of information as we try and 
transform what is 'real' into a communicable 'reality' (Gunder \& Hillier, 2004; Tilley, 2004). So it must be seen that communicated perceptions can only be partial.

“Dwelling” as expressed by Ingold (2000) (after Heidegger) can be considered as cultivating a sense of "time thickness", enhanced connectivity to the landscape or, in other terms, develop place attachment. As Janet Stephenson remarks “Landscape is ... always changing, carrying forward the threads of the past and weaving them into the future” (Stephenson, 2008 p.135). If this is the case then ill-conceived interventions can sever communities from their past (Antrop, 2005). Thus it can be seen that those who have an enhanced sense of attachment, are most vulnerable from development and need to be included in landscape issues. Such place attachment is also seen as a driver for acceptance to participate in issues relating to place (Höppner et al, 2008; Manzo \& Perkins, 2006).

\section{Involving the Public}

The ELC points to landscape as an arena for democratic governance, spreading the rights and at the same time the responsibility for the landscape to all actors, developing partnerships as opposed to imposing an 'elitist' landscape (CoE, 2000a, 2008; Scott, 2011). This implies a (normative) shift away from a top down approach, fitting with the recognition that a change to democratic processes is necessary if new forms of governance are to be genuinely inclusive. This fits with the view that within democratic systems processes are enhanced through public participation, increasing legitimacy as decisions gain higher authenticity if the public are included (Jones, 2007; Innes, 2004). 
Judith Innes notes that, as top down structures change to more flexible power networks distributed through society, new more complex networks are created based on the redistribution of power across society and between society and professionals (Innes, 2004). As such planning becomes seen as a more interactive communicative activity embedded within community, politics and public decision-making (Healey, 1996; Innes, 2003) with citizens placed at the centre of tackling societal problems (Home Office, 2004). This in turn places participation at the forefront of decision making.

There are extensive claims for participation as both a means and an end. As a means it is viewed that the durability and quality of decisions can be greatly improved if local considerations are taken into account. Through engaging citizens there is a greater sense of identification with the local area (Buchecker et al, 2003; CoE, 2000b) producing outcomes which reflect the interests of the participants and are better adapted to the local conditions. In such context it must be seen that locals' are experts in their own right, either on issues of personal interest or local issues that they are best placed to understand. This increases the likelihood that local needs are catered for (Reed, 2008). Local involvement should thus help facilitate the legitimacy and acceptance of decisions within society. This can be seen as allowing decisions to progress more smoothly as they are seen to be backed by the public.

As an end in itself participation is seen as providing benefits for democracy, citizenship and equality. Incorporating the public in the planning process provides the opportunity to instigate joint learning through which there comes a recognition of the legitimacy of 'others', providing the opportunity to build trust and common ground between participants (Innes, 2004). Enhanced trust further allows the development of 
social capital and networks, which can help to reframe identities in respect to wider issues at hand (Innes, 2003; Home Office, 2004; Reed, 2008). This should lead to the empowerment of society, providing minority groups a platform for voicing their values relating to issues impacting on their lives.

Participation is generally seen positively, as 'a warm persuasive word' (Hilyard et al, 2001). Yet participation has become an ambiguous concept, varying from mere information sharing to full empowerment, with the only measure of good participation often based on achieving self set goals. Moreover participation is no longer the revolutionary process it was once seen as, having been subsumed into the rhetoric of authority (Mosse, 2001). The question to be posed should be; do we only undertake participatory processes to support the planning and thus the political system by providing effectively 'engineered consent' (Hilyard et al, 2001)?

This questioning of participatory processes has resulted in a call for increased transparency and honesty, underpinned by a philosophy of "empowerment, equity, trust and learning” (Reed, 2008). It is seen that there is a need to recognise the diversity of issues and provide all knowledgeable individuals with the capacity for independence and the opportunity for participation, with all participating on the same even playing field (Healey, 1996; Sager, 2009). Providing for the complexity of society necessitates the engagement of 'weak groups', allowing those at risk of marginalisation, for example children or ethnic groups, an opportunity to be heard, developing empowerment (Reed, 2008; Berglund \& Nordin 2007).

Results from participatory processes are generated by amalgamations of arguments (Sager, 2005). It is this plurality that provides the diversity which should be 
central to participatory planning providing the catalyst for generating creativity (Sager, 2005; Healey, 1996). Such a recognition of plurality means respecting conflicts and tension. It can be said that if participation does not disrupt the official version of the truth then there is little impact and thus little reason for engaging the public in dialogue. However tension is most commonly interpreted by planners as antagonism and acted on likewise, with legal power used for resolution, developing 'consensus' (Pløger, 2004). An alternative is for planners to see this tension as 'agonism': as a recognised and legitimised conflict between equals (Mouffe, 1999). As opposed to resolving conflict with “engineered consent” founded on disingenuous harmony and based on unresolved tensions, a deeper understanding of the values and issues at stake and a realisation that true consensus, in practice, is unattainable would be more genuine.

Since Arnstein’s “Ladder of participation” (Arnstein, 1969) it has been considered that varied levels of participation are required for different processes and at different periods through a process. Within the framework of the International Association of Public Participation (IAP2), the lowest level of meaningful participation is seen as "Inform" where the public is helped to understand; "Consult" aims at gaining feedback from the public; "Involve" requires the consideration of public values and aspirations; "Collaborate" necessitates partnerships with the public to identify solutions; "Empower" represents the highest level of participation, placing final decision making in the publics hands (IAP2, 2007). The later three categories can be seen as more 'active participation'

It is considered that public participation should be initiated early in the process (Cox, 2006). In practice the public are often only included at stages of implementation when decisions have been made, and when it is seen by the participants that the process is 
purely to approve the decision makers conclusions (Reed, 2008; Innes \& Booher, 2004).

This is not entirely the fault of the authorities as it is easier for the public to appreciate change and become active when plans start to become physical reality (Reed, 2008 ).

\section{ELC and public involvement}

The ELC can be seen as a bastion for public participation within landscape issues, providing moral authority and a basis for member states to develop inclusionary strategies. As with other dimensions of the convention, participation is open to interpretation allowing nation states to engage the public as fits their legal and planning framework. Yet although implementation of participation is not clarified it is highlighted both implicitly and explicitly.

Implicitly the realisation that peoples’ perceptions are central to an understanding of landscape (Article 1.a) places participation as key to attaining a true insight into what landscape means. Additionally, the convention recognises that landscape is central to the lives of the populace, through providing a setting for living, providing an arena for expressing and developing shared heritage and a basis for identity (Article 5.a). In other words, landscape and its perception are developed through interaction with individuals and society, but at the same time the individuals and society are developed through their interaction with landscape. This points to a need for public involvement to understand what landscape means to those whose lives affect - and will be affected by - interventions as opposed to professionally led strategies, producing landscapes imposed on the public (Prieur \& Durousseau, 2006; Fry, 2001).

More directly the ELC explicitly calls for “...procedures for the participation of the general public... with an interest in the definition and implementation of the landscape 
policies...” (Article 5.c). Specifically public inclusion is viewed as necessary for Awarenessraising (Article 6A); “...increase awareness among the civil society... of the value of landscapes, their role and changes to them”, and Identification and assessment (Article 6C); “...taking into account the particular values assigned to them by the interested parties and the population concerned".

The elevation of participation within the ELC promotes landscape as a resource for all. As such participation should be seen as more than just handing over knowledge and hoping that it will be utilised effectively. As Michael Jones comments (Jones, 2007), participation within the ELC points to more than purely information exchange, it also has the possibility to develop democracy, legitimacy, tackling conflict, heterogeneity and provide social justice. Thus democratising of landscape needs to allow a just participation for all affected by issues regarding alterations of the landscape (Prieur \& Durousseau, 2006).

The Convention highlights the need for increased impetus to be placed on the views the populace holds of their landscapes, considering the "values assigned to them by the interested parties and the population concerned” (CoE, 2000a). Yet the ELC does not define the public. However, the United Nations Economic Commission for Europe's Aarhus Convention on Public Participation in Decision-making and Access to Justice on Environmental Matters, which forms part of the legal framework on which the ELC sits, defines 'public concerned' as "the public affected or likely to be affected by, or having an interest in, the environmental decision-making (UNECE, 1998). This definition implies all people should be included (Jones, 2007). But it cannot be viewed that all are affected 
equally, as local communities are not homogenous but reflect local constellations of power and influence.

According to the ELC recommendations, awareness-raising should be a way of clarifying the link between people, the activities they pursue during their daily lives and the characteristics of their surroundings (CoE, 2008). If awareness-raising is viewed in this light then it can be seen as developing the understanding that all have a stake in the landscape (Sevenant \& Antrop, 2010). The importance of ‘awareness raising’ can be seen as intrinsically linked to participation in so much as both pertain to knowledge transfer. 'Awareness raising' is commonly seen as a way of informing society, where the public is alerted to issues and meanings and values are promoted. With an entity such as landscape, where all have both a stake in and knowledge relating to, then awareness raising needs to be based on multidirectional knowledge transfer. As the Recommendations to the ELC (CoE, 2008) recognise, to be effective awareness raising should be a multidirectional process of knowledge dissemination between all concerned with the landscape.

Landscape Assessment can be considered central for fulfilment of the ELC, with assessment being a means for those nations who ratified the convention to "identify its own landscapes...”; “analyse their characteristics and the forces and pressures transforming them"; and "to take note of changes" within their own landscapes (CoE, 2000, Ch II, art. 6). It is viewed that such action must be based on detailed knowledge of the characteristics of each landscape, the evolutionary processes affecting it and taking into account values assigned to them by population concerned (Jones, 2007)

An assessment of the landscape can be seen as presenting a landscape for others to argue for values within the landscape and to provide insight and understanding of place 
(Stahlschmidt \& Nellemann 2009). In essence a landscape assessment can be seen as providing a solid knowledge base prior to planning interventions in the landscape. If landscape is to be seen as all-embracing, with significance for everyone (Lowenthal, 1986), then the assessment of such phenomena must be holistic (Fry, 2001; Tress et al., 2003). Addressing single aspects cannot facilitate a true appreciation of the landscape as, knowledge of the whole is based on a multiplicity of interlinked information (Stephenson, 2008; Tilley, 2004). As society and individuals perceptions are fundamental in the formation of the concept of landscape, their multiple and varied values and knowledge must be considered (CoE, 2000b).

At its most basic level inclusion of the public within landscape assessment can be seen as verification, gaining feedback from the public on analysis. Yet the aim should be for raising awareness of landscape, among professionals and society alike. As has been observed, perception of landscape is counterpart to its physical entity and can be seen as central to place attachment. If place attachment is seen as what bonds people to place, then the perceptions of landscape by those who dwell there should be central to both landscape assessment and awareness raising (Craik, 1986; CoE, 2000a).

\section{Landscape Character Assessment}

Landscape Character Assessment (LCA) is comprehensively used across England and Scotland for assembling base line knowledge which provides information for future planning and identifying landscape resources. The approach is principally based on Landscape Character Assessment, Guidance for England and Scotland (Swanwick, 2002), compiled in 2002, five years prior to the ELC coming into force in the UK. Yet 
LCA has been identified as a tool for contributing to the implementation of the ELC (Natural England, 2009). The LCA approach has since been developed outside the UK: in Sweden, Det Skånska Landsbygdprogrammet (Reiter, 2006), in Norway (Direktoratet for naturforvaltning \& Riksantikvaren, 2010), and in Denmark (Miljøministeriet, 2007).

Landscape characterisation is based on understanding and describing the variation between distinct landscape areas and types, identifying what makes each place special, rather than better or worse. This is based on the combination of elements present, which make up the character of the landscape. As such it is seen that all aspects play their part in defining character. The LCA approach is broadly divided up into two stages; characterisation and judgement.

Characterisation is seen as a relatively value free stage, defining and describing the landscape character areas and types. This first stage comprises of a desk study, where an initial understanding of the landscape is attained primarily through map analysis and preparation of overlays of different aspects, providing the context for draft landscape character areas/types. This is followed by a field study, which involves identifying the sensory elements, refining boundaries and corroborating desk study information. Classification brings together information of the landscape before dividing it into distinct recognisable areas and types with consistent common character.

Ultimately LCA is used as a tool to manage change, ensuring that changes are planned with consideration to their wider surroundings and if possible contribute positively to the landscape. This requires a move beyond description and classification to making judgement about the landscape informed by the characterisation. The judgements made are dependent on the final application of the assessment; if utilised for developing; 
landscape strategies, landscape guidelines, provide designated status or for understanding the capacity and sensitivity of the landscape for change. How these judgements are determined should be transparent and traceable from the characterisation process.

\section{LCA and public involvement}

LCA's are predominantly prepared by and used by professionals (Conrad et al., 2011), yet how the LCA guidelines define landscape echoes the definition within the ELC. Landscape is described as “... the relationship between people and place ... the setting for our day-to-day lives” and that "People's perceptions turn land into the concept of landscape” (Swanwick, 2002). This points to the significance of placing those who have an attachment to the place as central to any understanding of landscape and making perceptions relevant for any genuine assessment of the landscape. LCA provides the opportunity to bring public involvement in to the planning process at a very early stage and allows the opportunity for the public to be included in defining and identifying landscapes as outlined in ELC.

There is minimal information on how to operationalise public input in the LCA guidelines, however the benefit of some extent of stakeholder involvement especially at local scale and in judgements is mentioned. A more extensive, yet ambiguous, overview on how to incorporate the public into the assessment is outlined in Topic Paper 3 Landscape Character Assessment - How Stakeholders can help (Swanwick et al, 2002).

Within Topic Paper 3, 'stakeholders' are seen as individuals and groups with an interest in the landscape. The approach recognises a difference between 'communities of 
place' and 'communities of interest'. Communities of interest are identified as governmental bodies and NGO's etc, who can provide important base line info. 'Communities of place' are seen as those who live in the place; visitors to the area and businesses located in the area. It is seen that local communities have the greatest stake, but they also have the greatest diversity of issues and perspectives, which need to be listened to and understood (Swanwick et al, 2002). While this division of 'interest' and 'place' helps to simplify the multiplicity of stakeholders, it is actually difficult in reality to differentiate between the two. Specific interests will be held by those living in the place, and community of place is dependent on exclusion by defining boundaries. At the same time no communities can be seen as homogenous, static and harmonious units, with entirely shared visions and interests (Cooke \& Kothari, 2001). Although the division is contentious, we will retain this distinction as the assessments later reviewed are themselves based on this distinction.

Several questions are raised from the Topic Paper 3: whether to undertake an indepth approach with few participants or gain a shallow understanding from many; which phase of the assessment is best suited for feeding in public knowledge; which scale is most appropriate (LCA functions at various scales) (Swanwick et al, 2002)? There is uncertainty as to when stakeholders should be included. Several possible instances are identified for engaging 'communities of place'. These are at desk study stage, when defining the draft character areas, during classification and description, when deciding on the approach to judgement making and when making judgements. However, it is recognised that stakeholders should ideally be included as early as possible in the process. 
LCA operates at various scales nesting within each other and informing each other, from national or even European to regional and down to local. The scale influences what detail comes out and affects the efficiency and ability of when the public can be involved. It is seen that for communities of place, it is most appropriate to look at local scale. It is at this scale where people can relate to landscape and understand how landscape relates to their lives, the scale at which they 'dwell' (Ingold, 2000).

Public participation should result in a better informed assessment with greater ownership of the results, providing the opportunity to develop partnerships, increase awareness, develop commitment to outcomes, build consensus, increase local awareness; and validate character areas.

\section{Methodology}

To gain an understanding of how public involvement in LCA has been taken up in practice, an appraisal of all English, publically accessible LCA’s from 2007 - 2011 was undertaken. The reviewed documents were identified through the Natural England database and accessed via the internet between $25^{\text {th }}$ February 2011 and $25^{\text {th }}$ of April 2011. The year 2007 was chosen as the start date for reviewing the documents, as it corresponds with the point at which the ELC became binding in the UK (March 2007). Although many of the assessments started prior to this date, it can be considered that the rhetoric of the ELC had already been in position since ratification in 2006.

Fifty-two separate LCA's were accessed and assessed for their use of stakeholder involvement. This was undertaken primarily through addressing the method section of the document, searching for the terms consultation, participation, stakeholder and community 
and derivatives of these words. The initial search identified the assessments which incorporated 'communities of interest' and/or 'communities of place'. This was later refined to distinguish the LCA's which took up the inclusion of 'communities of place'.

Fourteen assessments, which were identified as including 'communities of place' were reviewed to address the extent to which public participation had been carried out in relation to representativeness, scope, phase of inclusion, knowledge sought and awareness raising. This was based on the project descriptions and information within documentation of the “participation”/"consultation” processes. These criteria were founded in theories and approaches outlined earlier in this paper, though they have been adapted to fit with the language used within cases which have been examined:

Representativeness - is divided into geographical representativeness and representation of interest. Geographical representativeness - addresses how inclusive participation has been in respect to representing the entirety of the area assessed; minimal coverage, partial coverage, and extensive coverage. Representation of interests addresses the level to which the approach engages those who inhabit the landscape (communities of place, dwellers); gaining feedback from local communities of interest; representatives of communities of place, or direct from communities of place, Scope of participation - considers, the depth to which those involved were included; informing the public on landscape issues; providing verification of professional based understanding of the landscape or professionals interpretation of the publics view; feeding information into the assessment through consultation; undertaking active participation where issues are discussed. It is not considered here that true empowerment 
can be achieved as this is a professional lead process - local community instigated initiatives can achieve empowerment, for examples see James and Gittins 2007 (James, 2007).

Phase of Inclusion - relates to timing of participation, (the categories have been adapted to reflect the LCA approach); desk study; draft character, classification and description; or judgement making

Knowledge sought - pertains to type of knowledge which was aimed at from the various assessments; scientific knowledge to supplement professional knowledge; knowledge of physicality of landscape to provide a local perspective of the physical landscape; perception as a sensed phenomena; or landscape perception as a lived experience

Awareness raising - considers the flow of information within the process; informing the public; gaining knowledge from the public; two way discussion - weak channels of communication (e.g. questionnaire in response to presentation); two way discussion - strong channels of communication (face to face); multidirectional knowledge transfer (e.g. workshops).

This methodological approach is similar to that utilised by Conrad et al. (2011), in so much as it addresses scope, representation and timing (phase of inclusion) of public participation. Conrad et al. also focus on the practicalities of participation, considering 'Comfort and convenience' and 'Influence' as criteria for evaluation, while this paper is more concerned with the type of knowledge gleaned and the transfer of information.

\section{Results}




\begin{tabular}{|c|c|c|c|c|c|c|c|c|c|}
\hline & \multicolumn{4}{|c|}{ Scope and Phase } & \multirow{3}{*}{$\begin{array}{l}\text { Landscape or } \\
\text { assessment }\end{array}$} & \multirow{3}{*}{$\begin{array}{l}\text { Knowledge } \\
\text { sought }\end{array}$} & & & \\
\hline & \multirow[t]{2}{*}{ Desk study } & \multirow{2}{*}{$\begin{array}{l}\text { Draft } \\
\text { character }\end{array}$} & \multirow{2}{*}{$\begin{array}{l}\text { Classification } \\
\text { and } \\
\text { description }\end{array}$} & \multirow[t]{2}{*}{ "judgements } & & & \multicolumn{2}{|c|}{ Representativeness } & \multirow[t]{2}{*}{ Awareness raising } \\
\hline & & & & & & & Geographic & Social & \\
\hline 1 & Consultation & & & & Landscape & $\begin{array}{l}\text { Sensed } \\
\text { perception }\end{array}$ & Extensive & $\begin{array}{l}\text { Community of } \\
\text { place }\end{array}$ & Two way (weak) \\
\hline 2 & & $\begin{array}{l}\text { Active } \\
\text { participation }\end{array}$ & & & Both & $\begin{array}{l}\text { Active } \\
\text { phenomenon }\end{array}$ & Limited & $\begin{array}{l}\text { Community of } \\
\text { place }\end{array}$ & Multidirectional \\
\hline 3 & Consultation & & $\begin{array}{l}\text { Verification- } \\
\text { consultation }\end{array}$ & & Both & $\begin{array}{l}\text { Sensed } \\
\text { perception }\end{array}$ & Extensive & $\begin{array}{l}\text { Community of } \\
\text { place }\end{array}$ & Two way (weak) \\
\hline 4 & & & Consultation & & Both & $\begin{array}{l}\text { Sensed } \\
\text { perception }\end{array}$ & Extensive & $\begin{array}{l}\text { Community of } \\
\text { place }\end{array}$ & One way \\
\hline 5 & & & & $\begin{array}{l}\text { Verification - } \\
\text { consultation }\end{array}$ & Assessment & Physicality & Partial & $\begin{array}{l}\text { Representatives of } \\
\text { community of place }\end{array}$ & Two way (strong) \\
\hline 6 & & & Verification & Consultation & Both & Physicality & Extensive & $\begin{array}{l}\text { Community of } \\
\text { place }\end{array}$ & Two way (weak) \\
\hline 7 & & Verification & Consultation & & Both & $\begin{array}{l}\text { Sensed } \\
\text { perception }\end{array}$ & Extensive & $\begin{array}{l}\text { Community of } \\
\text { place }\end{array}$ & Multidirectional \\
\hline 8 & & Verification & Verification & $\begin{array}{l}\text { Active } \\
\text { participation }\end{array}$ & Both & $\begin{array}{l}\text { Sensed } \\
\text { perception }\end{array}$ & Partial & $\begin{array}{l}\text { Community of } \\
\text { place }\end{array}$ & Multidirectional \\
\hline 9 & & $\begin{array}{l}\text { Verification- } \\
\text { consultation }\end{array}$ & $\begin{array}{l}\text { Verification- } \\
\text { consultation }\end{array}$ & & Assessment & Physicality & Partial & $\begin{array}{l}\text { Local communities } \\
\text { of interest }\end{array}$ & Multidirectional \\
\hline 10 & & & & Consultation & Landscape & $\begin{array}{l}\text { Sensed } \\
\text { perception }\end{array}$ & Extensive & $\begin{array}{l}\text { Community of } \\
\text { place }\end{array}$ & Two way (weak) \\
\hline 11 & & Verification & Verification & $\begin{array}{l}\text { Active } \\
\text { participation }\end{array}$ & Both & $\begin{array}{l}\text { Sensed } \\
\text { perception }\end{array}$ & Partial & $\begin{array}{l}\text { Representatives of } \\
\text { community of place }\end{array}$ & Multidirectional \\
\hline 12 & & & & Verification & Assessment & Physicality & Extensive & $\begin{array}{l}\text { Community of } \\
\text { place }\end{array}$ & One way \\
\hline 13 & & & & $\begin{array}{l}\text { Verification - } \\
\text { consultation }\end{array}$ & Assessmnt & Physicality & Partial & $\begin{array}{l}\text { Local communities } \\
\text { of interest }\end{array}$ & Multidirectional \\
\hline 14 & & Verification & & Consultation & Both & $\begin{array}{l}\text { Sensed } \\
\text { perception }\end{array}$ & Extensive & $\begin{array}{l}\text { Community of } \\
\text { place }\end{array}$ & Two way (strong) \\
\hline
\end{tabular}

Table 1

1. Blaby Landscape Character Assessment; 2. Cornwall and Isles of Scilly landscape Character; 3. East Lindsey District Landscape Character Assessment; 4. East Herts District Landscape Character Assessment; 5. Great Yarmouth Borough Landscape Character Assessment; 6. Guildford Landscape Character Assessment; 7. Hambleton and Howardian Hills Landscae Partnership Area landscape Character Assessment; 8. Havant Borough Landscape Assessment; 9. King's Lynn and West Norfolk Borough Landscape Character Assessment; 10. Lake Diststict National Park Landscape Character Assessment; 11. Peak District landscape Strategy and European Landscape Convention Action Plan; 12.

Teignbridge District landscape character Assessment; 13. Waveney District Landscape character Assessment; 14. Wirral Landscape Character Assessment and Visual Appraisal. 
Of the 52 assessments accessed, 28 included some form of stakeholder involvement, while 14 of the assessments considered the view of 'communities of place' to some degree. Involvement of the public in the landscape assessments accessed ranges from; a one way process, providing feedback on the assessment through web-portals, which allows data on discrepancies to be addressed by the public; through to extensive workshops which aim to attain knowledge of how the public perceive their landscape. The assessments addressing 'communities of place', were analysed further.

In relation to the criteria outlined in the method section (See table 1):

Scope and phase - Two assessments genuinely undertook participation that fed into the desk study, helping form an understanding of the local landscape prior to it being professionally framed. These were undertaken at the level of consultation, gaining information which could steer the assessments. Three assessments involved active participation, these were at different stages. Inclusion within The Cornwall and Isles of Scilly Assessment was undertaken at the draft character areas stage and fed into later stages. Both the Havant Borough Character Assessment and the Peak District Assessments included active participation at the judgement stage after the public had earlier been used to verify the professionals' work. Only one of the 14 assessments identified as involving 'communities of place’ went no further than verification. In general consultation was primarily used once areas had been defined, after the Draft Character phase.

Representativeness - Most of the assessments attempted some element of engaging the local community directly. Two assessments considered involving local interest groups as engaging the public, while two assessments engaged the populace indirectly through representatives. The degree to which the public were engaged varied from in-depth 
information gathering from a few individuals (Cornwall an Isles of Scilly) to a more extensive yet shallower inclusion of both community and visitors (Lake District National Park). The degree to which the public was included was reflected in the methods and approaches used, ranging from workshops to web accessible questionnaires.

Awareness-raising - All of the assessments accessed, including those which did not engage stakeholder, can be seen as raising awareness of landscape to some extent, due to the fact that they are easily accessible for the public to read. However the fourteen assessments that consider 'communities of place', achieved at least two way communication. It can be said that awareness raising relates to scope, so if only verification was considered then the process was more likely to result in rudimentary awareness-raising. However the majority went further with six of the assessments aiming at multidirectional knowledge transfer.

Knowledge sought - Only one of the assessments included methods which could be seen as engaging the view of landscape as perception of lived experience. Of the fourteen assessments which involved the local community, nine attempted to attain more than just an understanding of the physicality of the landscape, considering perception to some extent; Havant Borough Landscape Character Assessment considered stories and history as well as experience of the landscape; Hambleton and Howardian Hills Landscape Partnership Area LCA attempted to attain knowledge related to perceptions and sense of place.

\section{Discussion}

Within the Landscape Character Assessments studied, involvement of the public can be broadly divided into those which provided feedback about the landscape (e.g. Blaby LCA) or providing feedback on the assessment (e.g. King’s Lynn and West Norfolk Borough), in 
other words feedback on an expert view of the landscape. This latter approach is at odds with the ELC which considers that there is the need to "assess the landscapes thus identified, taking into account the particular values assigned to them by the interested parties and the population concerned” (CoE, 2000a Art 6 §C 1,a). Verification of, and consultation on the assessment document misses the perception of landscape held by those who 'dwell' in the place and, which is seen as central to an understanding of landscape as defined by the ELC. As Olwig argues the 'conventional' meaning of landscape has not arisen from an established theoretical top down definition but rather from perceptions, interests and practices. In such a way understanding of landscape should be shaped by "public discursive practice, rather than scientific reasoning” (Olwig, 2007 p.580).

Framing of the landscape by professionals in LCAs, prior to including the public, takes the form of defining boundaries within the landscape (landscape character areas) and providing a description of the landscape (landscape characterisation). As landscape is a continuous and multifarious entity (Antrop, 2000), boundaries and descriptions are imposed and are to an extent arbitrary, not necessarily reflecting the public's view of how the landscape functions. In such a way a new definition of the landscape is developed. This definition is based on an abstraction of official knowledge to create a new abstracted image, which represents the landscape (Monmonier, 1996). Such a redefinition of the landscape can alter the publics' perception of their own landscape (Scott, 2002). In this light it can be said that assessments which take in public views at an early stage (e.g. East Lindsey District LCA, Blaby LCA), have the opportunity to gain an enhanced understanding of the landscape prior to it being framed by professionals. The assessments, which considered the public prior to framing the landscape, utilised the knowledge gleaned to inform the desk study and further 
develop the assessment methodology by allowing the focus to be placed on what is considered significant.

Conversely it can be viewed that framing makes it easier for the public to identify with the abstract concept which is landscape (Scott, 2003; Reed 2008). This in turn makes it easier to engage with or represent the landscape and provide the opportunity to define the focus. For several of the assessments (e.g. Havant Borough, Hambleton and Howardian Hills Landscape Partnership \& Cornwall and Isles of Scilly) it can be seen that verification of the professional framing of the landscape provided a catalyst for further focused discussion on the publics’ landscape.

While output is needed for participation to be seen as 'leading somewhere' the main outcome from LCA is perhaps raising awareness of the differences within the landscape, based on multiple values. Awareness raising helps increase understanding of the landscape and the differences in perceptions and multiple values attached (CoE, 2008). While much of the focus of participation is combined to develop a generic, homogenised understanding of landscape, awareness raising allows more difficult issues to be considered and 'strife' to come to the forefront (Mouffe, 1999; Pløger, 2004). Unlike other stages of planning where at least a degree of consensus is needed to achieve acceptance, the assessment stage aims at understanding. This should be helped by the realisation that all have a common interest in the landscape even if the values attached to it differ. This can be seen as a starting point for development of holistic and mutually acceptable landscape strategies, an opportunity to engage the public meaningfully in the early stages of the planning process, when their knowledge and values can be heard. 


\section{Conclusion}

If participation is to be just, then there is a need to understand what participation entails and that it can be more than a means of knowledge transfer. So although increased participation is considered desirable it is not necessarily more participation which is needed but better participation. With issues relating to landscape, genuine public considerations need approaches which will: capture the diverse, intricate and sometimes intangible values which those who have attachment to the landscape place on it; communicate differences and raise awareness; communicate public knowledge into planning processes and yet still sit within practical restraints governing participation.

To attain landscape perceptions needs a realisation of the diversity of perceptions held by those influenced by the landscape. Approaches need to be able to aggregate the diversity of perceptions in such a way that they are understandable outside of the process in which they are formulated. Yet at the same time there is a need to be able to attain an in-depth understanding of embedded values. There would need to be an awareness of whose perceptions are being communicated and whose have been left out, and additionally a realisation that communicated perceptions are an incomplete representation of what is real. If landscape is seen as a hands on and lived entity, then landscape needs to be addressed where it impacts on those who inhabit the place, where the day to day understanding and perceptions of the landscape are encountered, in other words the local scale. While values attached to the landscape can be attained through involving the public in landscape assessment it must be understood that even an extensive approach to attaining the public values of landscape can only be representative of the public rather than truly represent the 
views of all; and even if no apparent values about a place are communicated, this does not mean that place has no values to individuals or society.

Public perception is both complex and problematic, yet if landscape is to be considered a perceived entity, it should be embraced as integral to understanding the landscape and thus for undertaking a landscape assessment. So although 'experts' views are invaluable for much of a landscape assessment they are unreliable for judging the values people attach to 'their' landscape. Landscape assessments can be viewed as an opportunity to develop multi-directional awareness raising, creating a broader understanding of what landscape means. Yet if assessments continue to be consultant focused then landscape can only be professional constructs as opposed to being defined by those who "dwell” within their everyday landscape.

\section{Reference list}

Antrop, M. (2000). "Background concepts for integrated landscape analysis." Agriculture, Ecosystems \& Environment 77(1-2): 17-28.

Antrop, M. (2005). "Why landscapes of the past are important for the future." Landscape and Urban Planning 70(1-2): 21-34.

Arnstein, S. R. (1969). "A ladder of citizen participation." Journal of the American Institute of Planners 34(4): 216-225. 
Berglund, U. and K. Nordin (2007). "Using GIS to make young people's voices heard in urban planning." Building Environment 33(4): 469-481.

Buchecker, M., M. Hunziker, et al. (2003). "Participatory landscape development: overcoming social barriers to public involvement." Landscape and Urban Planning 64(1-2): 29-46.

Canter, D. (1977). The Psychology of Place. London, The Architectural Press Ltd

Clemetsen, M., E. Krogh, et al. (2011). Landscape perception through participation : developing new tools for landscape analysis in local planning processes in Norway. The European Landscape Convention : challenges of participation M. Jones and M. Stenseke. Dortrecht, Springer: 219-237.

CoE. (2011). "Council of Europe in brief." Retrieved Retrieved 12/07/11, 2011.

CoE, C. o. E. (2000a). European Landscape Convention. Florence, Strasbourg: Council of Europe. CETS No 176.

CoE, C. o. E. (2000b). European Landscape Convention: Explanatory Report. Florence, Strasbourg, Council of Europe. CETS No. 176.

CoE, C. o. E. (2008). "Recommendation CM/Rec(2008)3 ofthe Commitee of Ministers to mamber states on the guidelines for the implementation of the European Landscape Convention." Retrieved 2011- 04-01.

Conrad, E., L. F. Cassar, et al. (2011). "Rhetoric and Reporting of Public Participation in Landscape Policy." Journal of Environmental Policy \& Planning 13(1): 23-47.

Cooke, B. and U. Kothari (2001). The case for Participation as Tyranny. Participation:The New Tyranny? B. Cooke and U. Kothari. London, Zed Books Ltd: 1-15.

Cox, R. (2006). Environmental Communication and the Public Sphere. Thousand Oaks, California, Sage 
Craik, K. (1986). Psychological reflections on landscape. Landscape meanings and values. E. Penning-Rowsell, \& Lowenthal, D. london, Allwen \& Unwin: 48-64.

EEA (2007). Europe's environment - the fourth assessment. Copenhagen, European Enviroment Agency.

Fry, G. (2001). "Multifunctional landscapes: towards transdisciplinaryresearch." Landscape and Urban Planning 57: 159-168.

Groening, G. (2007). "The "Landscape must become the law"'”or should it?" Landscape Research 32(5): 595 - 612.

Gunder, M. and J. Hillier (2004). "Conforming to the expectations of the profession: a Lacanian perspective on planning practice, norms and values." Planning Theory \& Practice 5(2): $217-235$.

Hague, C. and P. Jenkins (2005). Place, Identity, Participation and Planning. Abingdon, Oxon, Routledge.

Healey, P. (1996). The communicative turn in planning theory and its implications for spatial strategy formation. Readings in Planning Theory. S. F. Campbell, S. Oxford, Blackwell: 237-255.

Hilyard, N., P. Hegde, et al. (2001). Pluralism. Participation and Power: Joint Forest Managment in India. Participation the new Tyranny. B. Cooke and U. Kothari. London, Zed books: $56-71$.

Home Office. (2004). "What works in community involvement in area-based initiatives: A systematic review of literature " Retrieved 25/06/09, 2009.

Höppner, C., J. Frick, et al. (2008). "What Drives People's Willingness to Discuss Local Landscape Development?" Landscape Research 33(5): 605-622. 
IAP2. (2007). "IAP2 Spectrum of Public Participation www.iap2.org/associations/4748/files/IAP2\%20Spectrum_vertical.pdf." Retrieved 15/06/09, 2009.

Ingold, T. (2000). The Perception of the Environemnt. London, Routledge.

Innes, J. B., DE. (2003). Collaborative policy making: governance through dialogue. Deliberative Policy Analysis. M. Hajer, \& Wagenaar, H. Cambridge, UK, Cambridge University Press: 33-59.

Innes, J. E. (2004). "Consensus Building: Clarifications for the Critics." Planning Theory 3(1): $5-20$.

Innes, J. E., \& Booher, D. E., (2004). "Reframing Public Particiaption: Stratergies for the 21st Century." Planning Theory \& Practice 5(4): 419-436.

James, P. and J. W. Gittins (2007). "Local landscape character assessment: An evaluation of community-led schemes in cheshire." Landscape Research 32(4): 423-442.

Jones, M. (2007). "The European Landscape Convention and the Question of Public Particpation." Landscape Research 32(5): 613-633.

Lowenthal, D. (1986). Introduction. Landscape meanings and values. E. Penning-Rowsell, \& Lowenthal, D. London, Allen \& Unwin: 1-2.

Luginbühl, Y. (2006). "Landscape and individual and social well-being." Landscape and sustainable development: challenges of the European Landscape Convention. Strasbourg, Council of Europe Publishing: 29-51.

Manzo, L. C. and D. D. Perkins (2006). "Finding Common Ground: The Importance of Place Attachment to Community Participation and Planning." Journal of Planning Literature 20(4): 335-350. 
Miljøministeriet (2007). Vejledning om Landskabet i kommunenplanlægningen, Miljöministeriet.

Monmonier, M. (1996). How to lie with maps. Chicago, University of Chicago Press. Mosse, D. (2001). 'Pepole's Knowledge', participation and Patronage: Operations and Representation in Rural Developemnt. Participation:The New Tyranny? . B. Cooke and U. Kothari. London, Zed Books Ltd: 16-35.

Mouffe, C. (1999). "Deliberative democracy or agonistic pluralism?" Social Research 66(3): pp. 745-758.

Natural_England (2009). European Landscape Convention: Natural England’s 2009/2010 Action Plan http://www.naturalengland.org.uk/Images/ELC-actionplan0910_tcm620278.pdf retreived: 11/07/11, Natural England.

Naveh, Z. (2001). "Ten major premises for a holistic conception of multifunctional landscapes." Landscape and Urban Planning 57(3-4): 269-284.

Olwig, K. R. (2007). "The practice of landscape 'Conventions' and the just landscape: The case of the European landscape convention." Landscape Research 32(5): 579 - 594.

Oreszczyn, S. and A. Lane (2000). "The meaning of hedgerows in the English landscape: Different stakeholder perspectives and the implications for future hedge management." Journal of Environmental Management 60(1): 101-118.

Pløger, J. (2004). Strife: Urban Planning and Antagonism. Contemporary Movements in Planning Theory. J. Hillier, \& Healey, P. Aldershot, England, Ashgate Publishing. 3: 199-220. 
Prieur, M. (2006). Landscape and social, economic, cultural and ecological approaches. Landscape and sustainable development: challenges of the European Landscape Convention. Strasbourg, Council of Europe: 11-28.

Prieur, M. and S. Durousseau (2006). Landscape and public participation. Landscape and sustainable development: challenges of the European Landscape Convention. Strasbourg, Council of Europe Publishing: 165- 207.

Reed, M. S. (2008). "Stakeholder participation for environmental management: A literature review." Biological Conservation 141(10): 2417-2431.

Reiter, O. (2006). Det Skånska landsbgdsprogrammet - Ett utvecklingsprogram med landskapsperspektiv. Malmö, Lånsstyrelsen i Skåne Län.

Riksantikvaren, D. f. n. o. (2010). Landskapsanalyse: Framgangsmåte for vurdering av landskapskarakter og landskapsverdi, Direktoratet for naturforvaltning og Riksantikvaren

Sager, T. (2005). "Planning through inclusive dialogue: no escape from social choice dilemmas." Economic Affairs 25(4): 32-35.

Sager, T. (2009). "Planners' Role: Torn between Dialogical Ideals and Neo-liberal Realities." European Planning Studies 17(1): 65-84.

Scott, A. (2002). "Assessing public perception of landscape:the LANDMAP experience." Landscape Research 27(3): 271-295.

Scott, A. (2003). "Assessing Public Perception of Landscape: from practiec to Policy." Journal of Environmental Policy and Planning 5(2): 123-144. 
Scott, A. (2011). "Beyond the conventional: Meeting the challenges of landscape governance within the European Landscape Convention?" Journal of Environmental Management 92(10): 2754-2762.

Selman, P. (2006). Planning at the landscape scale. London, Routledge.

Sevenant, M. and M. Antrop (2010). "Transdisciplinary landscape planning: Does the public have aspirations? Experiences from a case study in Ghent (Flanders, Belgium)." Land Use Policy 27(2): 373-386.

Stahlschmidt, P. and V. Nellemann (2009). Metoder til Landskabsanalyse: Kortlǽgning af stedets karakter og potentiale, Forlaget Grønt Miljø

Stephenson, J. (2008). "The Cultural Values Model: An integrated approach to values in landscapes." Landscape and Urban Planning 84(2): 127-139.

Swanwick, C. (2002). Landscape Character Assessment, Guidance for England and Scotland http://www.landscapecharacter.org.uk/files/pdfs/LCA-Guidance.pdf. Landscape Character Assessment Guidance, Countryside Agency, Cheltenham and Scottish Natural Heritage, Edinburgh.

Swanwick, C., L. Bingham, et al. (2002). Topic Paper 3 - Landscape Character Assesment How Stakeholders can help. Landscape Character Assessment Guidance, Countryside Agency, Cheltenham and Scottish Natural Heritage, Edinburgh.

Tilley, C. (2004). The materiality of stone: explorations in landscape phenomenology. Oxford, Berg Publishers.

Tress, B., G. Tress, et al. (2003). Interdisciplinarity and transdisciplinarity in landscape studies the Wageningen DELTA approach. Interdisciplinary and Transdisciplinary Landscape 
Studies:Potential and Limitations. B. T. Tress, G;van der Valk, A Wageningen, Alterra Green World Research.

UNECE (1998). Aarhus Convention Convention on Access to Information, Public Participation in Decision-making and Access to Justice on Environmental Matters http://www.unece.org/env/pp/. Aarhus, UNECE, United Nations Economic Commision for Europe.

Uzzell, D. L. (1991). "Environmental psychological perspectives on landscape." Landscape Research 16(1): 3 - 10.

Wylie, J. (2007). Landscape. Abingdon, Oxfordshire, Routledge. 